\title{
IMPLEMENTATION OF FUZZY LOGIC CONTROLLERS TO MAINTAIN WATER TEMPERATURE IN HYDROPONICS NFT FOR LOLLO VERDE LETTUCE (LACTUCA SATIVA L.)
}

\author{
MOHAMAD NURKAMAL FAUZAN ${ }^{1}$, NYI MEKAR SAPTARINI ${ }^{*}$
}

${ }^{1}$ Applied Bachelor Program of Informatics Engineering, Pos Indonesia Polytechnic, West Java 40151, ${ }^{2}$ Department of Pharmaceutical Analysis and Medicinal Chemistry, Faculty of Pharmacy, Universitas Padjadjaran, West Java 45363

Email: nyi.mekar@unpad.ac.id

Received: 27 Aug 2020, Revised and Accepted: 06 Oct 2020

\section{ABSTRACT}

Objective: The purpose of this study was to maintain the nutritional water temperature in the range of $25-27^{\circ} \mathrm{C}$ for Lollo Verde lettuce (Lactuca sativa $\mathrm{L}$.).

Methods: The method was the Fuzzy Logic Mamdani (FLM) with two inputs, i.e. real time clock and temperature. The output was crisp speed PWM with the center of area method.

Results: The results showed that Fuzzy logic was succeeded in reducing water temperature in the NFT system from $28-32{ }^{\circ} \mathrm{C}$ to $26-27^{\circ} \mathrm{C}$, with an average delta of $3.5^{\circ} \mathrm{C}$. Fuzzy logic maintained the nutrient water temperature in the Lollo Verde lettuce with an average of $26.57 \pm 0.5^{\circ} \mathrm{C}$. Water temperature affected the yield of Lollo Verde lettuce.

Conclusion: The yield of NFT FLM system was better compared to the conventional NFT system.

Keywords: Nutrient film technique, Temperature maintenance, Fuzzy logic mamdani

(C) 2021 The Authors. Published by Innovare AcademicSciences Pvt Ltd. This is an open access article under the CC BYlicense (https://creativecommons.org/licenses/by/4.0/) DOI: https://dx.doi.org/10.22159/ijap.2021.v13s3.04 Journal homepage: https://innovareacademics.in/journals/index.php/ijap

\section{INTRODUCTION}

Hydroponics is an effective way to preserve water and planting space [1]. Hydroponic culture with the application of nutritional media, has become the second generation of the fastest growing crop production system and agricultural industry [2]. Planting vegetables hydroponic methods lead to economic value. Moreover, the market has begun to grow in accordance with the growing demand [3]. There are several hydroponic systems, including Nutrient Film Technique (NFT) [4]. There are several factors that affect the growth of hydroponic plants, including nutrient levels, acidity and water temperature in the system [5].

Water temperature affects the physiological processes during plant growth and development [6]. Hydroponic growth requires an ideal temperature system container, because the increased oxygen demand is proportional to plant growth [7-9]. An increased temperature around the plant roots will decrease dissolved oxygen levels in water. This causes the increased the pathogen growth, such as Pythium sp. [10-12] The ideal temperature of the nutrient solution is in the range of 18.3-26.6 ${ }^{\circ} \mathrm{C}[13]$ and for tropical plants in the range of $25-30^{\circ} \mathrm{C}[14,15]$.

Bandung, Indonesia, has two seasons, i.e. tropical heat/rain climate. The air temperature is $23.7 \pm 0.5^{\circ} \mathrm{C}$, with the lowest temperature is $17.9^{\circ} \mathrm{C}$ and the highest is $32.4{ }^{\circ} \mathrm{C}$ [16]. The temperature in our hydroponic system ranges from 28 to $32{ }^{\circ} \mathrm{C}$. In this study, the water temperature was cooled by utilizing the air environment temperature $[17,18]$. The purpose of this study was to maintain the nutritional water temperature in the range of $25-27{ }^{\circ} \mathrm{C}$ for Lollo Verde lettuce (Lactuca sativa L.) [19].

\section{MATERIALS AND METHODS}

\section{Materials}

This study was conducted in Sariasih, Bandung, West Java, Indonesia. The study used Lollo Verde lettuce as a plant sample, rockwool, reservoirs, pipes, fans, and Arduino.

\section{Methods}

\section{Hydroponic system design}

Hydroponic system was modified design which described by Fauzan and Saptarini [20]. Reservoir or container of $20 \mathrm{~L}$ for 30 Lollo Verde lettuce filled with $15 \mathrm{~L}$ of water $(75 \%)$. The NFT hydroponic system (fig. 1a) consists of 3 pipes filled with 10 pots that have input-fan and exhaust pipe with exhaust-fan of water flow. The volume of nutrient water per pipe ( 2.5 inch) with a length of $2 \mathrm{~m}$ was filled with $30 \%$, i.e. $2.1 \mathrm{~L}$. Three fans $(12 \mathrm{v}, 0.15 \mathrm{~A})$ were parallel arranged to cool the nutrient water temperature with an environment air temperature of $23.7 \pm 0.5{ }^{\circ} \mathrm{C}$. Arduino UNO r3 microcontroller (fig. 1b) control fan speed via PWM [21] with input set of DS3231 real time clock (RTC) at 0-23 and DS18B20 waterproof temperature sensor to read temperature values in Celsius units.

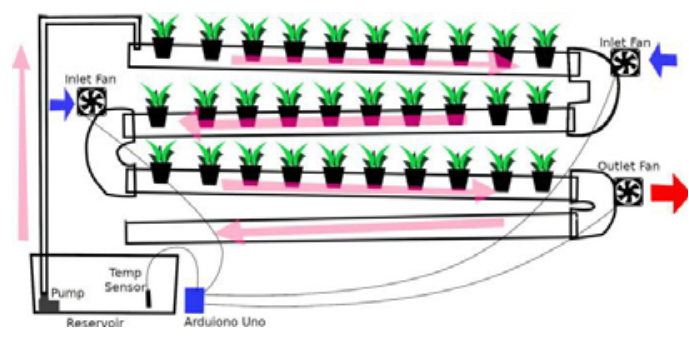

(a)



(b)

Fig. 1: NFT system design (a) and arduino UNO r3 block (b) 


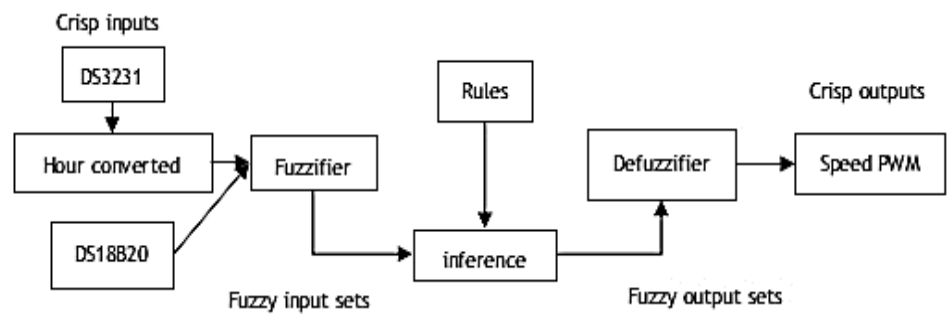

Fig. 2: Fuzzy logic controller

Fuzzy Logic Controller (FLC) [22] (fig. 2) was used to read two input parameters, i.e. (a) RTC input to convert hours 0-23 to 3-26, then entered into the time membership (table 1) and (b) temperature sensor input, then entered into the temperature membership (table 2). Both inputs produce outputs according to the PWM membership speed (table 3) through rules (table 4). Output in the form of speed PWM crisps value with the Center of Area (COA) method which is calculated by equation 1 [23].

$$
\mathrm{z}_{0}=\frac{\sum_{\mathrm{j}=1}^{\mathrm{n}} \mu\left(\mathrm{w}_{\mathrm{j}}\right) \cdot \mathrm{w}_{\mathrm{j}}}{\sum_{\mathrm{j}=1}^{\mathrm{n}} \mu\left(\mathrm{w}_{\mathrm{j}}\right)} \ldots(1)
$$

The defuzzified value was denoted as $z_{0}$. Here $w_{j}$ was indicate the sample element, $\mu\left(w_{j}\right)$ was the membership function, and $n$ was representing the number of elements in the sample [23].

Table 1: Time membership

\begin{tabular}{lll}
\hline Membership & Time & Time conversion \\
\hline Time1 & $21.00-3.00$ & $21-26$ \\
Time2 & $3.01-20.59$ & $3-21$ \\
\hline
\end{tabular}

Table 2: Temperature membership

\begin{tabular}{ll}
\hline Membership & Temperature $\left({ }^{\circ} \mathbf{C}\right)$ \\
\hline Cool & $0-25$ \\
Normal & $25-27$ \\
Hot & $27-50$ \\
\hline
\end{tabular}

Table 3: Speed membership

\begin{tabular}{ll}
\hline Membership & PWM speed \\
\hline off & 0 \\
mid & $100,128,140$ \\
max & 255 \\
\hline
\end{tabular}

Table 4: Fuzzy logic rules

\begin{tabular}{lll}
\hline Membership & Time1 (21-26) & Time2 (3-21) \\
\hline Cool & Off & Off \\
normal & Off & Mid \\
Hot & Mid & Max \\
\hline
\end{tabular}

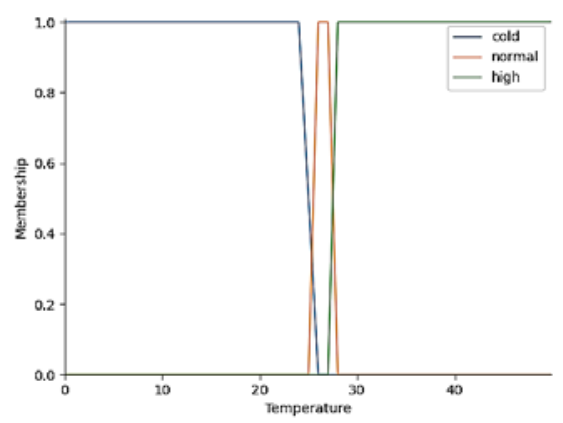

(a)
Time inputs were made into two memberships to simplify the calculations. The system was applied rules for time, i.e. if the hour value was less than 3 , the hour value was added to 24 to produce its conversion (table 1). Temperature inputs were divided into three memberships (table 2). The PWM speed output was 2 singletons and 1 triangular membership (table 3). Fuzzy logic was used the rules in table 4. The weight comparison of Lollo Verde lettuce between conventional NFT and NFT with FLC systems was done at harvest, i.e. $45 \mathrm{~d}$ after the seeding.

\section{Statistical analysis}

The Python 3.8.2 program was used for data plotting and statistical analysis.

\section{RESULTS AND DISCUSSION}

The Lollo Verde lettuce was used in this set-up to be tested with the hydroponic circuit as shown in fig. 1a to maximize the planting space. The Lollo Verde lettuces were planted on the rockwool slave with 3 hills per slave and implementing the NFT system. In this study, the temperature of nutrient water was considered the factors to be maintained. The temperature maintenance can achieve with compressed refrigeration techniques with the lowest temperatures was $5{ }^{\circ} \mathrm{C}$ [24]. Controlling vent fans and growlight can achieve an optimal temperature range of 10 to $35^{\circ} \mathrm{C}$ [25]. Light and temperature affected the final internode lengths (FIL) [26]. In the Cold Storage System Temperature study, Fuzzy produced crisp outputs which suitable for hot fan speeds and cold fan speeds of $6.55 \%$ and $70 \%$ respectively [27]. The considered factor was the temperature, which plants acceptable, i.e. $25-27^{\circ} \mathrm{C}$ for Lollo Verde lettuce [19].

In this study, a microcontroller was used to implement a fuzzy logicbased temperature control system. The purpose of the system was to control the water temperature by regulating the speed of a fan (fig. 1b). There were many ways to describe the variables linguistically, we choose the simple linguistic to simplify the task of the controller using fuzzy logic (fig. 2). Plots in fig. 3 and 4 were obtained from the Python program by entering the membership input and output parameters. Membership inputs, outputs, and rules were obtained from field observations (Sariasih, Bandung) and literature studies. The temperature membership plot was described the group of input values which read by the DS18B20 sensor (fig. 3a). The membership time plot was described the group of input values which read by RTC DS3231 (fig. 3b). The membership output plot was a variation of the PWM speed value from the range 0 to 255 (fig. 4).

Fig. 3: Input membership of temperature (a) and time (b) 


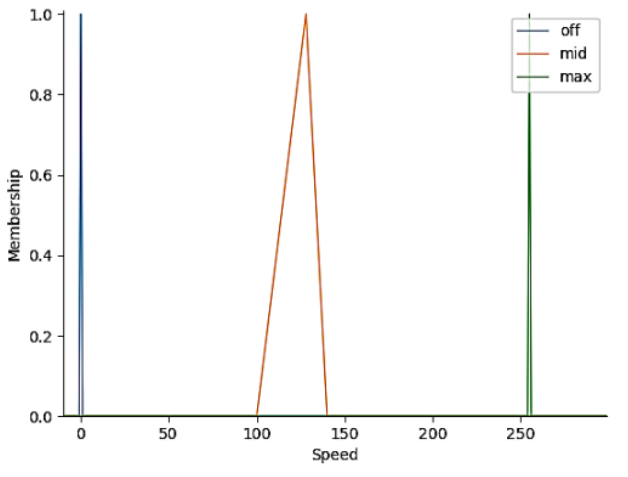

Fig. 4: Speed membership
Fig. 5 was obtained from the data recorded for $6 \mathrm{~d}$ and randomly taken at different hours from the morning to the night. This design was shown the exhausted water collide with the sucked air from the exhaust fan (2.29 inch x $2 \mathrm{~m})$ with a cross-sectional area of about $0.116 \mathrm{~m}^{2}$ on the surface. The ideal temperature was reached after 6 $d$ the system first runs (fig. 5). After the $6^{\text {th }}$ day, the water temperature showed a stable value, i.e. $26-27^{\circ} \mathrm{C}$.

Fig. 6 was obtained from the data recorded from 00.00 to 23.59 (converted from 0 to 26) to the response of fan speed output on the $7^{\text {th }}$ day. Fig. 7 was obtained from recorded data in the form of reading the value of the nutrient water temperature sensor to the fan speed output response on the $7^{\text {th }}$ day. The data in fig. 6 and 7 were carried out simultaneously, but processed with different parameters. Table 5 showed the weight comparison between the conventional NFT and NFT with FLC systems performed at harvest, which 10 plus $35 \mathrm{~d}$ from seeding.

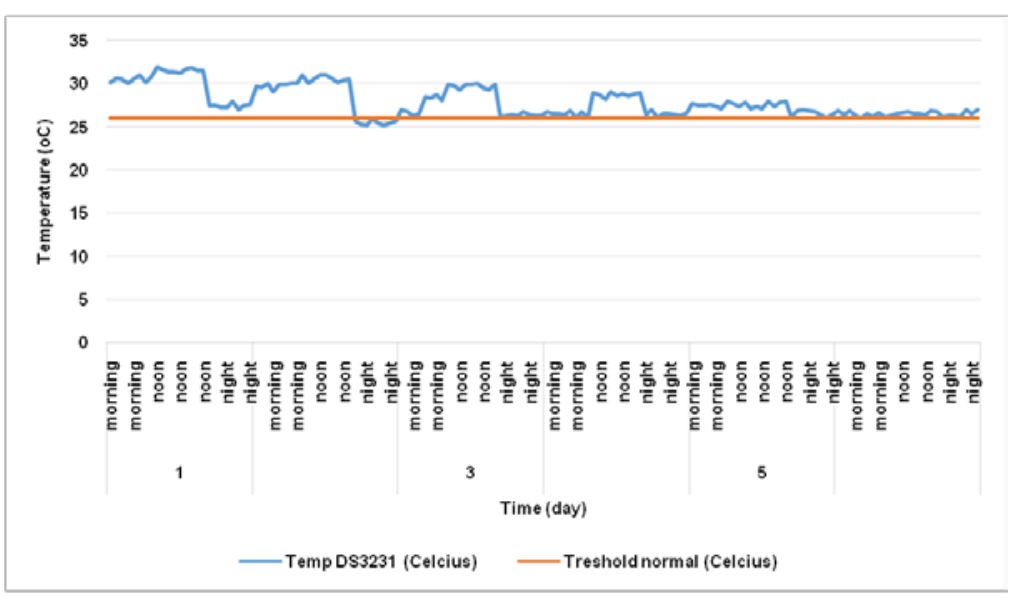

Fig. 5: Graph of time versus temperature

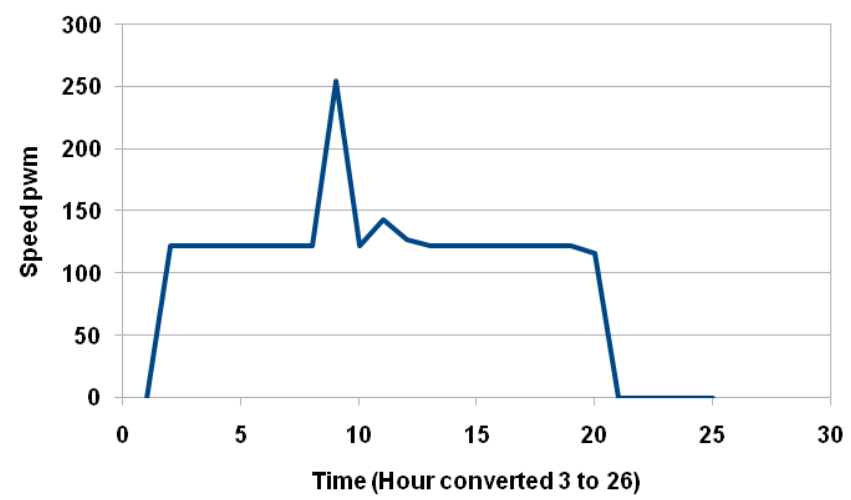

Fig. 6: Graph of time versus speed

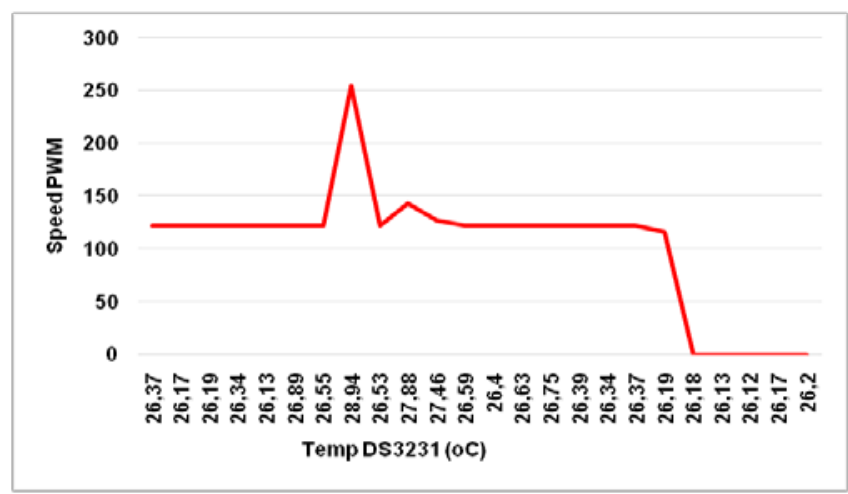

Fig. 7: The temperature sensor reading and PWM Speed response 
At night, temperatures were $17.9 \pm 0.2^{\circ} \mathrm{C}$, the exhaust fan did not work, due to the water temperature in the system was ideal (fig. 6). This was in accordance with the Fuzzy logic rules, so the speed output was 0 or a deadly condition. The results showed that even though the water temperatures were relatively stable, sometimes the DS18B20 temperature sensor was increased. Example, at $28.94^{\circ} \mathrm{C}$, the response of the fuzzy system produced a maximum output speed of 255 (fig. 7).
The fans were rotated according to the constructed rules (table 4). Fuzzy logic was succeeded in reducing water temperature in the NFT system, from $28-32{ }^{\circ} \mathrm{C}$ to $26-27{ }^{\circ} \mathrm{C}$, with an average delta of $3.5^{\circ} \mathrm{C}$. Fuzzy logic was succeeded in maintaining the nutrient water temperature in the Lollo Verde lettuce system, with an average of $26.57 \pm 0.5^{\circ} \mathrm{C}$. This temperature was in the recommended temperature range for Lollo Verde lettuce, i.e. $25-27^{\circ} \mathrm{C}$ [19].

Table 5: The weight comparison between the conventional NFT and NFT with FLC systems

\begin{tabular}{|c|c|c|c|c|c|c|c|c|}
\hline Pot no. & NFT (g) & NFT+FLC (g) & Pot no. & NFT (g) & NFT+FLC (g) & Pot no. & NFT (g) & NFT+FLC (g) \\
\hline 1 & 187 & 193 & 11 & 189 & 199 & 21 & 197 & 193 \\
\hline 2 & 183 & 192 & 12 & 192 & 199 & 22 & 189 & 193 \\
\hline 3 & 184 & 198 & 13 & 193 & 196 & 23 & 198 & 188 \\
\hline 4 & 188 & 185 & 14 & 200 & 184 & 24 & 183 & 195 \\
\hline 5 & 187 & 200 & 15 & 193 & 196 & 25 & 184 & 182 \\
\hline 6 & 197 & 184 & 16 & 198 & 189 & 26 & 200 & 183 \\
\hline 7 & 192 & 198 & 17 & 190 & 193 & 27 & 184 & 199 \\
\hline 8 & 184 & 198 & 18 & 194 & 182 & 28 & 196 & 184 \\
\hline 9 & 196 & 201 & 19 & 201 & 198 & 29 & 185 & 200 \\
\hline 10 & 183 & 200 & 20 & 181 & 185 & 30 & 196 & 189 \\
\hline
\end{tabular}

The weight comparison between the conventional NFT and NFT with FLC systems was performed on Lollo Verde lettuce, $10 \mathrm{~d}$ after seeding and transferred to the NFT system. The harvest on the $35^{\text {th }}$ day after planting on the NFT system. The weight of the Lollo Verde lettuce of the conventional NFT and NFT with FLC systems was $190.8 \pm 0.4 \mathrm{~g}$ and $192.5 \pm 0.2 \mathrm{~g}$, respectively (table 5 ). These results indicate that the NFT with FLC system was $0.9 \%$ better than the conventional NFT system. The inlet filters and suitable fan were needed for bigger hydroponic scales. This was aimed to reach the ideal temperature, which far from the ambient temperature. The ideal temperature can be maintained by other heat replacement techniques, such as a peltier or refrigerator and other input parameters, models, and methods. The test place with a different air environment temperature from this study was recommended to change the membership of the input, output, and rules in the program by considering other factors, such as plant type, location, hydroponic system, etc.

\section{CONCLUSION}

The yield of NFT FLM system was better compared to the conventional NFT system.

\section{FUNDING}

Nil

\section{AUTHORS CONTRIBUTIONS}

All the authors contributed equally.

\section{CONFLICT OF INTERESTS}

\section{Declared none}

\section{REFERENCES}

1. Tagle S, Benoza H, Pena R, Oblea A. Development of an indoor hydroponic tower for urban farming. Presented at the $6^{\text {th }}$ DLSU Innovation and Technology Fair; 2018. p. 1-7. Available from: https://www.dlsu.edu.ph/wp-

content/uploads/pdf/conferences/ditech/proceedings/volum e-3/paper-10.pdf [Last accessed on 15 Jul 2020]

2. Chow YN, Lee LK, Zakaria NA, Foo KY. New emerging hydroponic system. Int Malaysia Indonesia Thailand Symposium Innovation Creativity (iMIT-SIC) 2017;2:1-4.

3. Danial OM. Even though it doesn't have extensive agricultural land, Oded stretches the city of Bandung into vegetable selfsufficiency. Available from: https://bandungkita.id/2020/01/12/meski-tak-punya-lahanpertanian-luas-oded-usung-kota-bandung-swasembadasayuran/ [Last accessed on 12 Jan 2020].

4. Lennard W, Ward J. A comparison of plant growth rates between an NFT hydroponic system and an NFT aquaponic system. Horticulturae 2019;5:1-16.
5. Hyun Ju K, Young Son C, Oh Keun K, Myung Whan C, Jae Bok H, Soon Do B, et al. Effect of $\mathrm{pH}$ and $\mathrm{EC}$ of hydroponic solution on the growth of greenhouse rose. Asian J Plant Sci 2005;4:348-55.

6. Nxawe S, Ndakidemi P, Laubscher CP. Possible effects of regulating hydroponic water temperature on plant growth, accumulation of nutrients and other metabolites. Afr J Biotech 2011;9:9128-34.

7. Al-Rawahy MS, Al-Rawahy SA, Al-Mulla YA, Nadaf SK. Influence of nutrient solution temperature on its oxygen level and growth, yield and quality of hydroponic cucumber. J Agric Sci 2019;11:75-92.

8. Pedersen O, Perata P, Voesenek LACJ. Flooding and low oxygen responses in plants. Functional Plant Biol 2017;44:iii-vi.

9. Colombi T, Keller T. Developing strategies to recover crop productivity after soil compactio-a plant eco-physiological perspective. Soil Tillage Res 2019;191:156-61.

10. Rosberg AK, Wohanka W, Hultberg M, Alsanius BW. Implications on the root microbial community in the presence of Pythium ultimum in soilless cultivation systems. Acta Horticulturae 2019;1266:215-22.

11. Fortnum BA, Rideout J, Martin SB, Gooden D. Nutrient solution temperature affects pythium root rot of tobacco in greenhouse float systems. Plant Dis 2000;84:289-94.

12. How to cool your hydroponic reservoir. Available from: https://www.bigbloomhydroponics.com/hydro/how-to-coolyour-hydroponic-reservoir/ [Last accessed on 18 Jan 2020]

13. Five options to cool your hydroponic nutrient solution. Available from: https://www.saferbrand.com/articles/coolnutrient-solution [Last accessed on 18 Jan 2020]

14. Chil CD, Kim SY, Jeong JC, Lee YB. Solution temperature effects on potato growth and mineral uptake in hydroponic system. Acta Horticulturae 2001;548:517-22.

15. What is the ideal nutrient solution temperature in hydroponics? Available from: https://scienceinhydroponics.com/2017/06/what-is-theideal-nutrient-solution-temperature-in-hydroponics. html [Last accessed on 25 Jan 2020].

16. Meteorology Climatology and Geophysics Council. Average Temperature and Humidity Data; 2019. Available from: http://data.bandung.go.id/dataset/rata-rata-suhu-dankelembaban-udara-menurut-bulan-di-kotabandung/resource/9e2648b2-f237-4522-a365-268f3934626f [Last accessed on 20 Jan 2020].

17. Morrill JC, Bales RC, Conklin MH. Estimating stream temperature from air temperature: implications for future water quality. J Environ Eng 2005;131:139-46.

18. Mooij WM, De Senerpont Domis, LN Hülsmann S. The impact of climate warming on water temperature, timing of hatching and young-of-the-year growth of fish in shallow lakes in the netherlands. J Sea Res 2008;60:32-43. 
19. Daskalaki A, Burrage SW. Solution temperature and the uptake of water and nutrients by cucumber (Cucumis sativus L.) in hydroponics. Acta Horticulturae 1998;458:317-22.

20. Fauzan MN, Saptarini NM. Application of the mamdani fuzzy logic multi output method to maintain electrical conductivity in hydroponic media for lettuce (Lactuca sativa L.) and bok choy (Brassica rapa L.). J Global Pharma Tech 2020;12:634-40.

21. Arduino Uno Rev3. Store. Arduino. Cc, 1. Available from: https://store.arduino.cc/arduino-unorev3\%0Ahttps://store.arduino.cc/usa/arduino-uno-rev3 [Last accessed on 24 Jan 2020]

22. Lee CC. Fuzzy logic in control systems: fuzzy logic controllerI. IEEE Transactions Systems Man Cybernatics 1990;20:40418.

23. Lee CC. Fuzzy logic in control systems: fuzzy logic controllerII. IEEE Transactions Systems Man Cybernatics 1990;20:41935.
24. Kuncoro CBD, Sutandi T, Falahuddin MA. The development of the nutrient solution cooling system for the hydroponic cultivation. Unikom J 2017; V:67-72.

25. Fernando EAH, Bandala AA, Lim LAG, Maglaya AB, Ledesma N, Vicerra RR, et al. Design of a fuzzy logic controller for a vent fan and growlight in a tomato growth chamber. Proceeding of IEEE $9^{\text {th }}$ International Conference on Humanoid, Nanotechnology, Information Technology, Communication and Control, Environment and Management (HNICEM); 2017. p. 1-5.

26. Kahlen K, Zinkernagel J, Stutzel H. Modeling temperaturemodulated stem growth of cucumber plants (Cucumis sativus L.). Proceeding of IEEE $4^{\text {th }}$ International Symposium on Plant Growth Modeling, Simulation, Visualization and Applications; 2012. p. 188-91.

27. Kumar AS, Sudha S. Design of wireless sensor network based fuzzy logic controller for a cold storage system. Proceeding of IEEE $7^{\text {th }}$ Power India International Conference (PIICON); 2016. p. 1-6. 